Zhi-Yun Dong*, Fu-Gui Xi and Xing-Yu Xu

\title{
The crystal structure of 3,3'-
}

\section{((carbonylbis(azanediyl))bis(ethane-2,1-diyl)) bis(1-methyl-1H-benzo[d]imidazol-3-ium) tetrafluoroborate monohydrate, $\mathrm{C}_{21} \mathrm{H}_{28} \mathrm{~N}_{6} \mathrm{O}_{3} \mathrm{~B}_{2} \mathrm{~F}_{8}$}

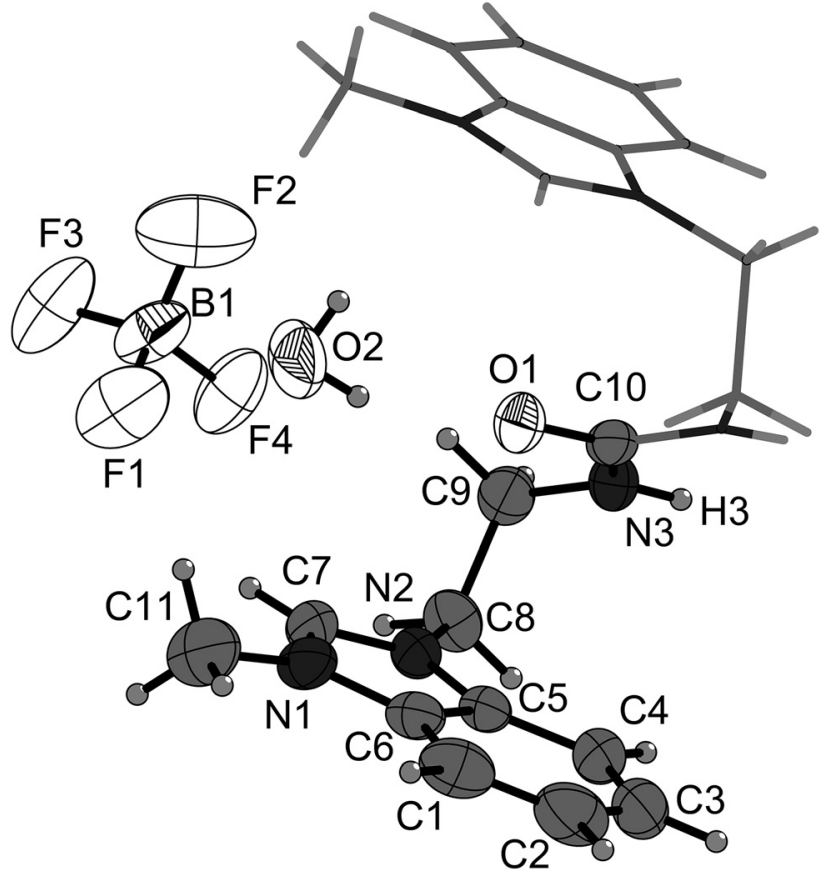

https://doi.org/10.1515/ncrs-2020-0646

Received December 29, 2020; accepted January 14, 2021; published online February 1, 2021

\section{Abstract \\ $\mathrm{C}_{21} \mathrm{H}_{28} \mathrm{~N}_{6} \mathrm{O}_{3} \mathrm{~B}_{2} \mathrm{~F}_{8}$, orthorhombic, Pccn (no. 56), $a=17.7949(19) \AA, b=9.3979(10) \AA, c=15.3455(16) \AA$, $V=2566.3(5) \AA^{3}, Z=4, R_{g t}(F)=0.0567, w R_{r e f}\left(F^{2}\right)=0.1846$, $T=296(2) \mathrm{K}$.}

CCDC no.: 830078

\footnotetext{
*Corresponding author: Zhi-Yun Dong, Department of Chemistry, Xinzhou Teachers University, Xinzhou, Shanxi, 034000, P. R. China, E-mail: 16dongzhiyun@163.com. https://orcid.org/0000-0001-5219. 8045

Fu-Gui Xi and Xing-Yu Xu, Department of Chemistry, Xinzhou Teachers University, Xinzhou, Shanxi, 034000, P. R. China
}

Table 1: Data collection and handling.

\begin{tabular}{|c|c|}
\hline Crystal: & Colorless block \\
\hline Size: & $0.25 \times 0.15 \times 0.07 \mathrm{~mm}$ \\
\hline Wavelength: & Mo $K \alpha$ radiation $(0.71073 \AA$ 我 \\
\hline$\mu:$ & $0.14 \mathrm{~mm}^{-1}$ \\
\hline Diffractometer, scan mode: & $\varphi$ and $\omega$ \\
\hline$\theta_{\max }$, completeness: & $28.1^{\circ},>99 \%$ \\
\hline$N(h k l)_{\text {measured }}, N(h k l)_{\text {unique }}, R_{\text {int }}:$ & $32,623,3127,0.053$ \\
\hline Criterion for $I_{\mathrm{obs}}, N\left(h k l_{\mathrm{gt}}\right.$ : & $I_{\mathrm{obs}}>2 \sigma\left(I_{\mathrm{obs}}\right), 1897$ \\
\hline$N(\text { param })_{\text {refined }}:$ & 183 \\
\hline Programs: & $\begin{array}{l}\text { Bruker [1], SHELX [2-4], refinement } \\
{[5], \text { Olex2 [6] }}\end{array}$ \\
\hline
\end{tabular}

Table 1 contains crystallographic data, and Table 2 contains the list of the atoms including atomic coordinates and displacement parameters.

\section{Source of material}

A solution of $N$-methylbenzimidazole $1.32 \mathrm{~g}(10 \mathrm{mmol})$ and

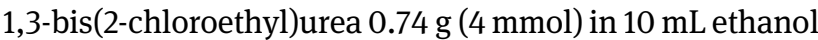
was heated at $353 \mathrm{~K}$ for $38 \mathrm{~h}$ under $\mathrm{N}_{2}$. After that the reaction mixture was cooled to room temperature, the white precipitate was collected and dissolved in $50 \mathrm{~mL}$ distilled water, and silver tetrafluoroborate $0.78 \mathrm{~g}(4 \mathrm{mmol})$ was added. In order to prevent the silver salt decomposing when exposed to light, the whole system was put in a dark place and stored at room temperature $5 \mathrm{~h}$, removed the white $\mathrm{AgCl}$ precipitate, and finally evaporated the filtrate in vacuum. Colourless block crystals were grown from methanol by slow evaporation at ambient room temperature over a period of 2 weeks. Yield: $91 \%$. ${ }^{1} \mathbf{H}$ NMR (500 MHz, DMSO- $\mathrm{d}_{6}$ ): $\delta$ (ppm) 3.41-3.44 (m, 4H), $4.11(\mathrm{~s}, 6 \mathrm{H}), 4.49(\mathrm{t}, J=6.0 \mathrm{~Hz}, 4 \mathrm{H}), 6.85(\mathrm{br}, 2 \mathrm{H}), 7.64-7.68$ (m, 4H), 8.01-8.07 (m, 4H), $10.04(\mathrm{~s}, 2 \mathrm{H}) ;{ }^{13} \mathbf{C}$ NMR (125 MHz, DMSO-d $\mathrm{d}_{6}$ ): $\delta$ (ppm) 33.18, 38.43, 47.18, 113.40, $113.44,126.26,126.29,130.92,131.79,143.18,157.98$. 
Table 2: Fractional atomic coordinates and isotropic or equivalent isotropic displacement parameters $\left(\AA^{2}\right)$.

\begin{tabular}{|c|c|c|c|c|}
\hline Atom & $x$ & $y$ & $z$ & $U_{\text {iso }} * / U_{\text {eq }}$ \\
\hline 1 & 0.750000 & 1.250000 & $-0.46741(13)$ & $0.0587(6)$ \\
\hline V1 & 90084 (10) & $1.0697(2)$ & $-0.35090(12)$ & $.0560(5)$ \\
\hline N2 & 85795 (10) & 99322 (19) & $-0.47440(12)$ & $.0454(4)$ \\
\hline N3 & 74597 (11) & $1.1287(2)$ & $-0.59464(12)$ & $.0501(5)$ \\
\hline 43 & 0.748929 & 1.134014 & -0.650482 & $0.060^{*}$ \\
\hline 1 & 99436 (14) & $1.2472(3)$ & $05(2)$ & 0.0704 (8) \\
\hline 1 & 1.012511 & 1.280701 & 57507 & $0.085^{\star}$ \\
\hline 2 & 02111 (15) & $6(3)$ & $2(3)$ & $844(10)$ \\
\hline 2 & 1.058155 & 1.367445 & -0.489254 & $0.101^{*}$ \\
\hline 3 & (14) & $6(4)$ & $-0.5684(2)$ & $.0793(9)$ \\
\hline $3 A$ & 001 & 641 & 9869 & $0.095^{\star}$ \\
\hline 4 & 93897 (13) & $1.1450(3)$ & $-0.57293(17)$ & $.0604(7)$ \\
\hline 4 & 63 & 445 & 5981 & $0.072^{\star}$ \\
\hline 5 & 11) & $1.0 \mathrm{~s}$ & -0.4 & $0.0448(5)$ \\
\hline C6 & 2) & (3) & -0.4 & $9(6)$ \\
\hline $\mathrm{C} 7$ & 85328 (12) & 0.98 & (15) & $0.0523(6)$ \\
\hline 7 & 795 & 33 & 9617 & $0.063^{*}$ \\
\hline 8 & 8111 & 0.91 & -0.53 & $0.0562(6)$ \\
\hline $8 \mathrm{~A}$ & 03 & 33 & 463 & $0.067^{\star}$ \\
\hline $8 B$ & 80 & 56 & 577 & $067^{*}$ \\
\hline 9 & 7369 & 0.99 & -0.5 & $0.0559(6)$ \\
\hline $9 \mathrm{~A}$ & 0.706696 & 146 & 2726 & $.067^{\star}$ \\
\hline $9 B$ & 0.709798 & 1.00 & 399 & $.067^{*}$ \\
\hline 10 & 000 & 000 & -0.54 & $0.0469(7)$ \\
\hline 11 & 9120 & 1.08 & $-0.25698(17)$ & 0.0894 (11) \\
\hline $11 \mathrm{~A}$ & 0.94 & 358 & -0.245382 & $0.134^{\star}$ \\
\hline 11B & 0.865625 & 09 & 9797 & $0.134^{\star}$ \\
\hline $111 \mathrm{C}$ & 0.928134 & 0.992164 & 3972 & $0.134^{\star}$ \\
\hline 31 & 65409 (19) & $0.8933(5)$ & $-0.2890(2)$ & $0.0760(10)$ \\
\hline $\mathrm{F} 1$ & $0.71942(11)$ & $0.9327(3)$ & $0.24738(12)$ & $0.1138(8)$ \\
\hline $\mathrm{F} 2$ & $0.60551(16)$ & $1.0003(3)$ & $-0.2864(2)$ & $0.1612(12)$ \\
\hline F3 & $0.62177(14)$ & $0.7791(3)$ & $-0.24795(14)$ & $0.1301(10)$ \\
\hline F4 & $0.67229(11)$ & $0.8532(2)$ & $-0.37147(11)$ & $0.0955(6)$ \\
\hline $02^{\mathrm{a}}$ & $0.7355(12)$ & $1.231(3)$ & $-0.2835(3)$ & $0.105(6)$ \\
\hline $\mathrm{H} 2 \mathrm{~A}^{\mathrm{a}}$ & 0.702052 & 1.278446 & -0.301414 & $0.158^{*}$ \\
\hline $\mathrm{H} 2 \mathrm{~B}^{\mathrm{a}}$ & 0.753411 & 1.237550 & -0.332969 & $0.158^{*}$ \\
\hline
\end{tabular}

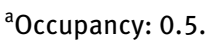

\section{Experimental details}

The structures were solved by direct methods using SHELXT [3] and refined with SHELXL [4] following established refinement strategies [5] via OLEX-2 [6]. Carbonbound $\mathrm{H}$ atoms were placed in calculated positions $(\mathrm{C}-\mathrm{H}$ $0.95 \AA$ ) and were included in the refinement in the riding model approximation, with $U_{\text {iso }}(\mathrm{H})$ set to $1.2 U_{\text {eq }}(\mathrm{C})$. All other hydrogen atoms bonded to heteroatoms were located on a difference Fourier map.

\section{Comment}

Ionic liquids are salts that can melt at temperatures below $100{ }^{\circ} \mathrm{C}$ and are typically composed of large and unsymmetrical organic cations and organic or inorganic anions [7]. ILs have been recognized as new green solvents for chemical reactions [8], extractions [9], catalysis [10], gas absorption [11], and promising candidate materials for electrolytes in electrochemical devices [12].

The asymmetric unit of the title compound contains one half of a bisbenzimidazolium diaction, one tetrafluoroborate anion and water molecules near to a two-fold axis with an occupancy of 0.5 (see the Figure), and lattice water was omitted for clarity. The bond lengths and angles are all in the expected ranges [13]. A carbon-oxygen double bonds exist in the compound, the $\mathrm{C}-\mathrm{O}$ bond distance $(\mathrm{C} 10-\mathrm{O} 1)$ is 1.222(4) $\AA$, the angles of $\mathrm{O} 1-\mathrm{C} 10-\mathrm{N} 3$ and $\mathrm{N} 3-\mathrm{C} 10-\mathrm{N}^{\mathrm{i}}$ $\left({ }^{i}=1.5-x, 2.5-y, z\right)$ are $122.6(3)^{\circ}$, respectively. The counter tetrafluoroborate anions are located at the side of the benzimidazolium ring, the benzimidazolium group can make a strong interaction with tetrafluoroborate through $(\mathrm{C}-\mathrm{H})^{+}-\mathrm{X}^{-}$type ionic hydrogen bonding, where the ionic hydrogen-bonding distances are $2.496 \AA\left[(\mathrm{C} 7-\mathrm{H} 7)^{+}-\mathrm{F} 1\right]$, and $2.471 \AA$ [(N3-H3) $\left.-\mathrm{F}^{\mathrm{ii}}{ }^{\mathrm{ii}}=1.5-\mathrm{x}, \mathrm{y},-0.5+\mathrm{z}\right]$. There is also an intermolecular $\pi-\pi$ stacking interaction (distance = $3.749 \AA$ ̊).

Author contributions: All the authors have accepted responsibility for the entire content of this submitted manuscript and approved submission.

Research funding: Scientific and Technological Innovation Programs of Higher Education Institutions in Shanxi (STIP).

Conflict of interest statement: The authors declare no conflicts of interest regarding this article.

\section{References}

1. BRUKER. SAINT, APEX2 and SADABS; Bruker AXS Inc.: Madison, Wisconsin, USA, 2009.

2. Sheldrick G. M. A short history of SHELX. Acta Crystallogr. 2008, A64, 112-122.

3. Sheldrick G. M. SHELXT - integrated space-group and crystal-structure determination. Acta Crystallogr. 2015, A71, 3-8.

4. Sheldrick G. M. Crystal structure refinement with SHELXL. Acta Crystallogr. 2015, C71, 3-8.

5. Müller P. Practical suggestions for better crystal structures. Crystallogr. Rev. 2009, 15, 57-83. 
6. Dolomanov O. V., Bourhis L. J., Gildea R. J., Howard J. A. K., Puschmann H. OLEX2: a complete structure solution, refinement and analysis program. J. Appl. Crystallogr. 2009, 42, 339-341.

7. Dong K., Liu X., Dong H., Zhang X., Zhang S. Multiscale studies on ionic liquids. Chem. Rev. 2017, 117, 6636-6695.

8. Clarke C. J., Tu W. C., Levers O., Brohl A., Hallett J. P. Green and sustainable solvents in chemical processes. Chem. Rev. 2018, 118, 747-800.

9. Toledo H., Ariel A. C., Maximo G. J., Costa M. C., Batista E. A. C., Meirelles A. J. A. Applications of ionic liquids in the food and bioproducts industries. ACS Sustain. Chem. Eng. 2016, 4, 5347-5369.
10. Salikolimi K., Sudhakar A. A., Ishida Y. Functional ionic liquid crystals. Langmuir 2020, 36, 11702-11731.

11. Yan S., Han F., Hou Q., Zhang S., Ai S. Recent advances in ionic liquid-mediated $\mathrm{SO}_{2}$ capture. Ind. Eng. Chem. Res. 2019, 58, 13804-13818.

12. Zhao Y., Bostrom T. Application of ionic liquids in solar cells and batteries: a review. Curr. Org. Chem. 2015, 19, 556-566.

13. Kathuria L., Samuelson A. G. Chiral $N$-heterocyclic carbeneiridium complexes for asymmetric reduction of prochiral ketimines. Polyhedron 2021, 195, 114976. 